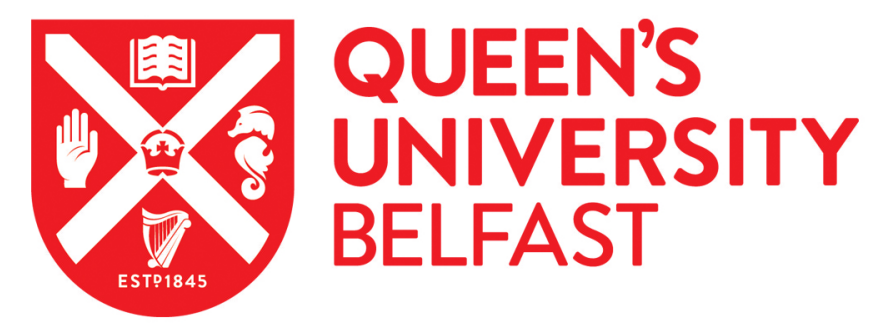

\title{
Environmental implications of low nitrogen use efficiency in excessively fertilized hot pepper (Capsicum frutescens L.) cropping systems
}

Zhu, J. H., Li, X. L., Christie, P., \& Li, J. L. (2005). Environmental implications of low nitrogen use efficiency in excessively fertilized hot pepper (Capsicum frutescens L.) cropping systems. Agriculture, Ecosystems and Environment, 111(1-4), 70-80. https://doi.org/10.1016/j.agee.2005.04.025

Published in:

Agriculture, Ecosystems and Environment

Queen's University Belfast - Research Portal:

Link to publication record in Queen's University Belfast Research Portal

\section{General rights}

Copyright for the publications made accessible via the Queen's University Belfast Research Portal is retained by the author(s) and / or other copyright owners and it is a condition of accessing these publications that users recognise and abide by the legal requirements associated with these rights.

Take down policy

The Research Portal is Queen's institutional repository that provides access to Queen's research output. Every effort has been made to ensure that content in the Research Portal does not infringe any person's rights, or applicable UK laws. If you discover content in the Research Portal that you believe breaches copyright or violates any law, please contact openaccess@qub.ac.uk. 


\title{
Environmental implications of low nitrogen use efficiency in excessively fertilized hot pepper (Capsicum frutescens L.) cropping systems
}

\author{
J.H. Zhu ${ }^{\text {a,b }}$, X.L. Li ${ }^{\text {a,* }}$, P. Christie ${ }^{\text {a,c }}$, J.L. Li ${ }^{\text {a }}$ \\ ${ }^{a}$ Key Laboratory of Plant Nutrition, Ministry of Agriculture, Key Laboratory of Plant-Soil Interactions, Ministry of Education and \\ Department of Plant Nutrition, China Agricultural University, Beijing 100094, China \\ ${ }^{\mathrm{b}}$ Institute of Forest Ecology, Environment and Protection, Chinese Academy of Forestry, Beijing 100091, China \\ ${ }^{\mathrm{c}}$ Agricultural and Environmental Science Department, Queen's University Belfast, Newforge Lane, Belfast BT9 5PX, UK
}

Received 19 February 2004; received in revised form 12 April 2005; accepted 14 April 2005

Available online 24 June 2005

\begin{abstract}
A randomized-block greenhouse plot experiment was conducted on $\mathrm{N}$ utilization efficiency and $\mathrm{N}$ losses in intensive hot pepper (Capsicum frutescens L.) production systems typical of commercial practice in Shouguang, an important vegetable production area in Shandong province, northeast China. Crop yield and $\mathrm{N}$ utilization, soil mineral $\mathrm{N}$ dynamics and potential nitrate leaching losses were studied in control plots receiving no $\mathrm{N}$ fertilizer or organic manure and in experimental plots receiving $0,600,1200$ or $1800 \mathrm{~kg}$ urea-N ha ${ }^{-1}$ plus a basal dressing of $15 \mathrm{tha}^{-1}$ air-dried poultry manure supplying $178 \mathrm{~kg} \mathrm{~N} \mathrm{ha}^{-1}$. Ammonia volatilization from the soil surface was monitored. A microplot was established in each of the plots receiving $1200 \mathrm{~kg}$ urea- $\mathrm{N} \mathrm{ha}^{-1}$ (the local average commercial fertilizer $\mathrm{N}$ application rate), the urea applied to the microplot was labelled with 10 atom $\%{ }^{15} \mathrm{~N}$ tracer and residual soil ${ }^{15} \mathrm{~N}$ and ${ }^{15} \mathrm{~N}$ in harvested plant parts were determined. Previous intensive cropping led to a very high residual soil mineral $\mathrm{N}$ content $\left(1117 \mathrm{~kg} \mathrm{~N} \mathrm{ha}^{-1}\right)$ before the experiment began and control plots gave a satisfactory mean fruit yield of $5.7 \mathrm{t} \mathrm{DM} \mathrm{ha}^{-1}$ with no significant yield response to applied fertilizer and poultry manure. Only $10 \%$ of applied fertilizer $\mathrm{N}$ was recovered in the aboveground parts of the crop and about $52 \%$ was lost from the soil-plant system. Substantial nitrate leaching losses occurred using the two highest fertilizer $\mathrm{N}$ application rates but there was little $\mathrm{NH}_{3}$ volatilization from the soil surface. In a survey of 94 wells in Shouguang, the $\mathrm{NO}_{3}{ }^{-}-\mathrm{N}$ concentrations in water used for drinking and irrigation were determined. Almost half of 94 local wells surveyed had $\mathrm{NO}_{3}{ }^{-}-\mathrm{N}$ concentrations above the USEPA public drinking water maximum contaminant level of $10 \mathrm{mg} \mathrm{L}^{-1}$. The data indicate that $\mathrm{N}$ inputs for intensively managed vegetable crops in northeast China should be reduced urgently to maintain crop yields while avoiding serious long-term environmental damage.
\end{abstract}

(C) 2005 Elsevier B.V. All rights reserved.

Keywords: Fertilizer $\mathrm{N}$ use efficiency; Nitrogen inputs; ${ }^{15} \mathrm{~N}$; Intensive cultivation; Nitrate leaching; Environmental protection

\footnotetext{
* Corresponding author. Tel.: +86 1062731325 ; fax: +86 1062731016.

E-mail address: lixl@cau.edu.cn (X.L. Li).
} 


\section{Introduction}

Nitrogen fertilizer application rates have increased dramatically in intensive agricultural systems in north China in recent years. The fertilizer $\mathrm{N}$ application rates used for vegetable production in north China range from about $500-1900 \mathrm{~kg} \mathrm{~N}^{-1}$ (Zhang et al., 1996). Even higher total $\mathrm{N}$ inputs are often used for greenhouse vegetable crops by mixing poultry manure into the soil for each crop and growing annually two or more crops. Nitrogen fertilizers are important in vegetable production systems but there is concern about the potential for nitrate leaching and groundwater contamination (Rossi et al., 1991; Barraclough et al., 1992; Cameron et al., 1997; Li et al., 2001; Zhu et al., 2004). Leaching of $\mathrm{NO}_{3}{ }^{-}-\mathrm{N}$ occurs in many vegetable production areas because $\mathrm{N}$ application rates often exceed crop demand (Biernbaum, 1992; Jackson et al., 1994; McNeal et al., 1995). High inputs of $\mathrm{N}$ and excessive irrigation make these intensive production areas particularly sensitive to nitrate leaching (Power and Schepers, 1989; McPharlin et al., 1995). In addition, plants do not make use of all the $\mathrm{N}$ applied and farmers incur economic loss by applying more $\mathrm{N}$ than is required to obtain a positive yield response (MacDonald et al., 1989). Over fertilization in north China has led to high concentrations of nitrate in groundwater and drinking water (average of $68 \mathrm{mg} \mathrm{L}^{-1}$ ) and crop recoveries below $40 \%$ of applied $\mathrm{N}$ in some areas (Zhang et al., 1996). According to Biernbaum (1992), the key to reducing groundwater contamination by nitrate due to leaching or runoff is to define clearly the water and nutrient requirements of plants. In the meantime, the recommended rates of $\mathrm{N}$ for maximum yields of vegetables vary greatly depending on soil fertility and vegetable variety (McPharlin et al., 1995) and are difficult to determine.

Greenhouse vegetable production has developed rapidly in northeast China during the last 2 decades. Shouguang $\left(36^{\circ} 02^{\prime} \mathrm{N}, 118^{\circ} 45^{\prime} \mathrm{E}\right)$, one of the most important vegetable production areas, supplies vegetables to a number of major cities including Beijing and Shanghai. According to the 2001 Statistical Data published by Shouguang Statistical Bureau, Shouguang had 50,000 ha of land under vegetable production by the end of the year 2000, of which $80 \%$ comprised greenhouse crops in some 320,000 greenhouses. Fertilizer $\mathrm{N}$ is often applied at $>1200 \mathrm{~kg} \mathrm{~N} \mathrm{ha}^{-1}$ and irrigation water at $1000 \mathrm{~mm}$ per crop and two or three crops are grown each year. There is a clear potential for high nitrate leaching in these intensive systems ( $\mathrm{Li}$ et al., 2001; Zhu et al., 2004) and lower fertilizer inputs are urgently required for environmental protection. There is little information on vegetable crop $\mathrm{N}$ utilization and nitrate losses under these intensive greenhouse production conditions and studies are needed on sustainable vegetable nutrition in relation to environmental quality. Hot pepper, the third most popular major greenhouse vegetable grown in the region (after kidney bean and tomato), was selected for the present study. The aims were to: (i) determine hot pepper $\mathrm{N}$ utilization efficiency under different fertilizer $\mathrm{N}$ application rates; (ii) quantify the amount of $\mathrm{N}$ lost via nitrate leaching and $\mathrm{NH}_{3}$ volatilization; (iii) evaluate the feasibility of decreasing $\mathrm{N}$ inputs to protect the environment without reducing crop yield.

\section{Materials and methods}

\subsection{Experimental greenhouse}

The study was conducted at Shouguang, Shandong Province, from February to July 2001. A 4-year-old plastic greenhouse $8.5 \mathrm{~m} \times 70 \mathrm{~m}$ with a sandy loam soil was selected within which an experimental area of $8 \mathrm{~m} \times 48 \mathrm{~m}$ in size was divided into $8 \mathrm{~m} \times 2.4 \mathrm{~m}$ (20) plots. Four replicates of five treatments were allocated to the plots in a randomized block design. Plastic film was installed from the soil surface down to $90 \mathrm{~cm}$ between adjacent plots to isolate the plots hydrologically to this depth. No supplementary illumination or heating was used. The air temperature occasionally fell to $14{ }^{\circ} \mathrm{C}$ and the maximum usually exceeded $28{ }^{\circ} \mathrm{C}$ in spring. The summer mean minimum and maximum air temperatures were 24 and $42{ }^{\circ} \mathrm{C}$. All the water for the crops was provided by irrigation (Table 1).

\subsection{Experimental treatments}

There were five treatments supplying different $\mathrm{N}$ application rates: (1) control (no fertilizer or organic manure); (2)-(5) basal dressing of $1.5 \mathrm{~kg} \mathrm{~m}^{-2}$ air- 
Table 1

Selected soil physico-chemical properties at three depth increments in the experimental greenhouse before the experiment was set up $(n=3)$

\begin{tabular}{|c|c|c|c|c|c|c|c|c|c|}
\hline \multirow[t]{2}{*}{ Soil property } & \multicolumn{3}{|l|}{$0-30 \mathrm{~cm}$} & \multicolumn{3}{|c|}{$30-60 \mathrm{~cm}$} & \multicolumn{3}{|c|}{$60-90 \mathrm{~cm}$} \\
\hline & Mean & S.D. & $\mathrm{CV}$ & Mean & S.D. & $\mathrm{CV}$ & Mean & S.D. & $\mathrm{CV}$ \\
\hline$\delta_{\mathrm{d}}$ & 1.256 & 0.060 & 4.8 & 1.265 & 0.030 & 2.4 & 1.285 & 0.049 & 3.8 \\
\hline Total N & 0.30 & 0.03 & 9.6 & 0.23 & 0.02 & 8.5 & 0.15 & 0.05 & 21.5 \\
\hline $\mathrm{OM}$ & 1.74 & 0.15 & 8.6 & 0.98 & 0.19 & 19.1 & 0.76 & 0.07 & 9.5 \\
\hline $\mathrm{pH}$ & 6.61 & 0.11 & 1.6 & 6.66 & 0.14 & 2.1 & 6.74 & 0.05 & 0.8 \\
\hline $\mathrm{NO}_{3}{ }^{-}-\mathrm{N}$ & 143.1 & 8.9 & 6.2 & 80.5 & 10.2 & 12.7 & 68.8 & 23.4 & 34.0 \\
\hline Olsen P & 172.4 & 14.6 & 8.4 & 50.3 & 26.0 & 51.7 & 16.9 & 5.2 & 30.6 \\
\hline Exch. K & 357.6 & 98.3 & 27.5 & 230.6 & 66.0 & 28.6 & 166.9 & 34.9 & 20.9 \\
\hline
\end{tabular}

$\delta_{\mathrm{d}}$, bulk density $\left(\mathrm{g} \mathrm{cm}^{-3}\right)$; total $\mathrm{N}(\%)$; OM, organic matter $(\%)$; $\mathrm{NO}_{3}{ }^{-}-\mathrm{N}\left(\mathrm{mg} \mathrm{kg}^{-1}\right)$; Olsen $\mathrm{P}, \mathrm{NaHCO}_{3}$-extractable $\mathrm{P}\left(\mathrm{mg} \mathrm{kg}^{-1}\right)$; Exch. $\mathrm{K}$, $\mathrm{NH}_{4} \mathrm{OAc}$-exchangeable $\mathrm{K}\left(\mathrm{mg} \mathrm{kg}^{-1}\right)$; S.D., standard deviation; $\mathrm{CV}$, coefficient of variation $(\%)$.

dried chicken manure equivalent to $178 \mathrm{~kg} \mathrm{~N} \mathrm{ha}^{-1}$ and basal dressings of $524 \mathrm{~kg} \mathrm{P}$ and $996 \mathrm{~kg} \mathrm{~K}$ together with split applications of $0,600,1200$ or $1800 \mathrm{~kg} \mathrm{~N}$ urea-N $\mathrm{ha}^{-1}$. The average and maximum rates of fertilizer $\mathrm{N}$ used in this region are about 1200 and $1800 \mathrm{~kg} \mathrm{ha}^{-1}$ and these two treatments were, therefore, intended to indicate the average and maximum nitrate leaching losses under conventional practice. The urea applications were split into seven doses that were applied with irrigation during the growing season (Table 2). Total furrow irrigation was about $1000 \mathrm{~mm}$, similar to local commercial practice, over the whole growing period. Irrigation water samples supplied $244 \mathrm{~kg} \mathrm{NO}_{3}{ }^{-}-\mathrm{N}$ and $10 \mathrm{~kg} \mathrm{NH}_{4}^{+}-\mathrm{N} \mathrm{ha}^{-1}$.

\subsection{Soil and plant sampling and analysis}

Six soil cores $3.5 \mathrm{~cm}$ in diameter were taken to $180 \mathrm{~cm}$ depth from each plot before planting and after harvesting, sectioned into 0-30, 30-60, 60-90, 90$120,120-150$ and $150-180 \mathrm{~cm}$ depth increments and combined to give composite samples. Sub-samples were used to determine moisture content and $0.01 \mathrm{M}$ $\mathrm{CaCl}_{2}$-extractable inorganic $\mathrm{N}$. The freshly collected samples were stored on ice and all analyses were initiated within $24 \mathrm{~h}$ of sampling. Concentrations of $\mathrm{NH}_{4}{ }^{+}-\mathrm{N}$ and $\mathrm{NO}_{3}{ }^{-}-\mathrm{N}$ were determined with a Bran and Luebbe Model TRAACS 2000 continuous-flow analyzer. Soil water content was determined gravimetrically after drying for $24 \mathrm{~h}$ at $105^{\circ} \mathrm{C}$. Hot pepper fruit samples were taken from each plot on every harvest date for determination of fresh and dry weights. All the fruit samples from the same plot were broken up and mixed for total $\mathrm{N}$ determination. To simulate commercial practice, the plants were pulled out of the soil at the final harvest and some roots remained in the soil. Plant samples were taken from each plot after harvesting, separated into leaves, petioles and stems, chopped, mixed and weighed before and after drying at $80^{\circ} \mathrm{C}$ for $48 \mathrm{~h}$. Yield (marketable portion) and total plant biomass (removed from the plot) were recorded and Kjeldahl $\mathrm{N}$ was determined in fruit and plant biomass samples.

Table 2

Chronology of field operations, irrigation, planting dates and harvest dates in 2001

\begin{tabular}{|c|c|c|}
\hline $\begin{array}{l}\text { Date } \\
\text { (in 2001) }\end{array}$ & $\begin{array}{l}\text { Field } \\
\text { operations }\end{array}$ & $\begin{array}{l}\text { Fertilizer } \\
\mathrm{N} \text { inputs } \\
\text { (\% fertilizer } \\
\mathrm{N} \text { applied) }\end{array}$ \\
\hline 25 February & Soil solution samplers installed & \\
\hline 25 February & Leachate collectors installed & \\
\hline 26 February & Beds established, $60 \mathrm{~mm}$ irrigation & \\
\hline 4 March & Chicken manure, $100 \mathrm{~mm}$ irrigation & \\
\hline 5 March & Seedlings transplanted & \\
\hline 28 March & $100 \mathrm{~mm}$ irrigation & \\
\hline 12 April & Fertilization, $90 \mathrm{~mm}$ irrigation & 10 \\
\hline 20 April & Fertilization, $90 \mathrm{~mm}$ irrigation & 10 \\
\hline 26 April & Fruit harvest & \\
\hline 2 May & Fertilization, $110 \mathrm{~mm}$ irrigation & 10 \\
\hline 5 May & Fruit harvest & \\
\hline 11 May & Fertilization, $110 \mathrm{~mm}$ irrigation & 20 \\
\hline 13 May & Fruit harvest & \\
\hline 19 May & Fruit harvest & \\
\hline 20 May & Fertilization, $120 \mathrm{~mm}$ irrigation & 20 \\
\hline 27 May & Fruit harvest & \\
\hline 29 May & Fertilization, $130 \mathrm{~mm}$ irrigation & 20 \\
\hline 6 June & Fruit harvest & \\
\hline 13 June & Fertilization, $90 \mathrm{~mm}$ irrigation & 10 \\
\hline 26 June & Fruit harvest & \\
\hline 6 July & Fruit harvest & \\
\hline 11 July & Fruit and straw harvest & \\
\hline
\end{tabular}




\subsection{Soil solution and leaching water sampling and analysis}

Suction cups are very useful for in situ measurement of available $\mathrm{N}$ in soil profiles (Kengni et al., 1994). Three ceramic porous cups were installed at depths of 20,50 and $80 \mathrm{~cm}$ in each plot. Soil solution samples were collected 3-5 days after irrigation when soil water content had returned to saturation. The soil solution samples extracted from the porous cups were filtered in situ and then stored frozen. Mineral $\mathrm{N}$ concentrations in the thawed soil solution samples were measured with the TRAACS analyzer. It was assumed that the $\mathrm{NO}_{3}{ }^{-}-\mathrm{N}$ content of the soil solution extracted at $20 \mathrm{~cm}$ was representative for the $0-30 \mathrm{~cm}$ layer, at $50 \mathrm{~cm}$ represented the 30 $60 \mathrm{~cm}$ layer and at $80 \mathrm{~cm}$ represented the $60-90 \mathrm{~cm}$ layer.

Nitrate leaching losses are normally measured and simulated with soil core lysimeters (Moyer et al., 1996; Jabro et al., 1997). Leaching water was sampled with a modified lysimeter installed at $90 \mathrm{~cm}$ depth in each plot (Fig. 1). A PVC plate containing water washed sands was used to collect and filter the water leached below $90 \mathrm{~cm}$. The soil core above the plate

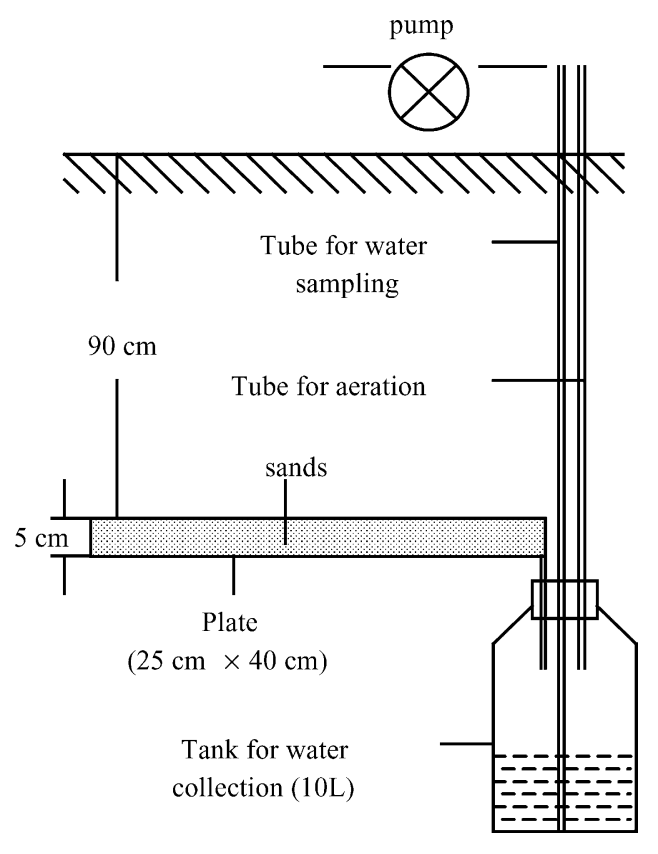

Fig. 1. Design of lysimeter for collecting leaching water. was undisturbed, while the plate was inserted from a hole at $90 \mathrm{~cm}$, which was $1 \mathrm{~m}$ from the centre of the soil core (Fig. 1). The leaching water samples were pumped out 7 days after each irrigation event or 1 day before the next irrigation event. Sub-samples were deep-frozen immediately after determination of the volume of leaching water. Inorganic $\mathrm{N}$ in leaching water was also measured with the TRAACS analyzer. Nitrate-N leaching below $90 \mathrm{~cm}$ was calculated from the formula $N=\left[\mathrm{NO}_{3}{ }^{-}-\mathrm{N}\right] V$, where $\left[\mathrm{NO}_{3}{ }^{-}-\mathrm{N}\right]$ is the nitrate- $\mathrm{N}$ concentration in the leaching water, $V$ the volume of collected leaching water and $N$ is the amount of nitrate- $\mathrm{N}$ expressed in mass per unit area. Since the roots of hot pepper rarely reached a depth $90 \mathrm{~cm}$, the nitrate in the water collected was considered to represent that leached out of the root zone and therefore unavailable for plant uptake.

\subsection{Microplot study using ${ }^{15} \mathrm{~N}$-labelled urea}

A $0.6 \mathrm{~m} \times 0.7 \mathrm{~m}$ microplot was set up in each of the plots receiving $1200 \mathrm{~kg}$ fertilizer $\mathrm{N} \mathrm{ha}^{-1}$ and the urea applied to this part of the plot, split into seven doses with irrigation as in the main plot, was labelled with 10 at. $\%{ }^{15} \mathrm{~N}$. The microplot was separated from the remainder of the plot by sheet iron from $10 \mathrm{~cm}$ above soil surface to $90 \mathrm{~cm}$ depth. All hot pepper fruits were collected and weighed during the growing period and leaves and stems were sampled and weighed at harvest. Soil was sampled after final harvest to a depth of $180 \mathrm{~cm}$ and was sectioned into $6 \mathrm{~cm} \times 30 \mathrm{~cm}$ increments. Total $\mathrm{N}$ content in soil and plant material was determined by semi-micro Kjeldahl digestion. Residual soil ${ }^{15} \mathrm{~N}$ and ${ }^{15} \mathrm{~N}$ in harvested plant parts were determined using a Nuclide mass spectrometer.

\subsection{Ammonia volatilization}

An instrument was designed to collect $\mathrm{NH}_{3}$ volatilized from the soil surface as shown in Fig. 2. Two pieces of sponge were immersed with $20 \mathrm{~mL}$ glycerol phosphoric acid $(5 \%, \mathrm{v} / \mathrm{v}$, phosphoric acid and $4 \%, \mathrm{v} / \mathrm{v}$, glycerol) before installation in a PVC cylinder $15 \mathrm{~cm}$ in diameter and $12 \mathrm{~cm}$ high. The base of the cylinder was inserted $1 \mathrm{~cm}$ into the soil. The lower sponge was used to absorb $\mathrm{NH}_{3}$ volatilized from the soil surface in the cylinder and the upper sponge to 


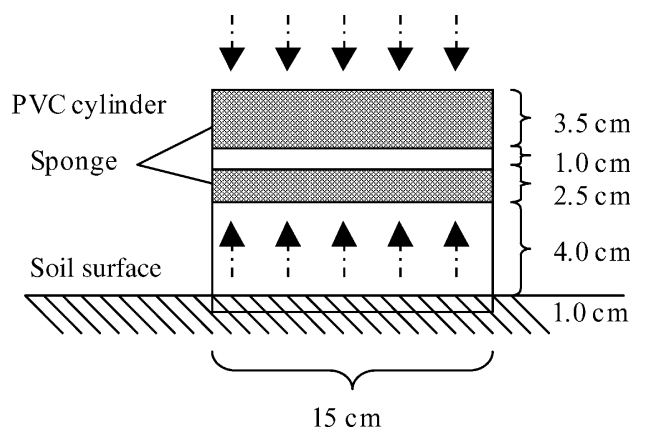

Fig. 2. Design of instrument for collecting ammonia volatilized from the soil surface.

absorb $\mathrm{NH}_{3}$ from outside the cylinder and to prevent its absorption by the lower sponge. The instrument was installed immediately after fertilizer application or irrigation. The lower sponge was replaced with new one after 24 or $48 \mathrm{~h}$ and the upper sponge was changed every 3 days. The sponges were taken to the laboratory and extracted with $500 \mathrm{~mL}$ of $1 \mathrm{M} \mathrm{KCl}$ for $1 \mathrm{~h}$. About $100 \mathrm{~mL}$ equilibrium liquid was sampled and stored frozen before analysis using the TRAACS auto analyzer.

\subsection{Well water survey}

Water samples used for drinking and irrigation were collected from a depth of 20-30 m in 94 wells in the Shouguang area and analyzed for $\mathrm{NO}_{3}{ }^{-} \mathrm{N}$ to obtain some information on $\mathrm{N}$ enrichment in the local groundwater. The position of each well was recorded according to whether it was in the northern, southern, eastern or western sector of Shouguang. The water samples were analyzed for $\mathrm{NO}_{3}{ }^{-}-\mathrm{N}$ using a TRAACS auto analyzer as described above.

\subsection{Data analysis}

Data were tested by analysis of variance. Mean values of crop yields and $\mathrm{N}$ offtakes were compared by Duncan's multiple range test at the 5\% level.

\section{Results and discussion}

\subsection{Crop yield and $N$ utilization}

Crop yields and $\mathrm{N}$ offtakes of hot pepper in the greenhouse experiment at harvest are shown in Table 3. Although all plots receiving additional $\mathrm{N}$ showed higher shoot and total aboveground (fruit + shoot) yields than unamended control plots, the fruit yields were not significantly lower in the controls. Thus, fertilizer and organic manure $\mathrm{N}$ inputs increased the yields of the less important parts of the crop without any effect on the important component, namely the fruit. Moreover, the total crop offtake of $\mathrm{N}$ increased with increasing fertilizer $\mathrm{N}$ application rate with no increase in fruit yield. The highest fertilizer $\mathrm{N}$ application rate tested $\left(1800 \mathrm{~kg} \mathrm{~N} \mathrm{ha}^{-1}\right.$, the highest rate used in commercial practice in Shouguang) can therefore be regarded as excessive and even the second-highest rate $\left(1200 \mathrm{~kg} \mathrm{~N} \mathrm{ha}^{-1}\right.$, the average local commercial rate) is excessive in terms of fruit yield response.

Table 3

Dry matter yield and $\mathrm{N}$ offtake of fruit and shoots (stems and leaves) of hot pepper under a range of fertilizer $\mathrm{N}$ application rates

\begin{tabular}{|c|c|c|c|c|c|c|}
\hline \multirow[t]{2}{*}{ Treatment $\left(\mathrm{kg} \mathrm{N} \mathrm{ha}^{-1}\right)$} & \multicolumn{3}{|c|}{ Dry matter yield $\left(\mathrm{t} \mathrm{ha}^{-1}\right)$} & \multicolumn{3}{|c|}{ Crop $\mathrm{N}$ offtake $\left(\mathrm{kg} \mathrm{N} \mathrm{ha}^{-1}\right)$} \\
\hline & Fruit & Shoot & Total & Fruit & Shoot & Total \\
\hline Control $^{\mathrm{a}}$ & $5.71 \mathrm{a}^{\dagger}$ & $6.13 b$ & $11.8 \mathrm{~b}$ & $129 \mathrm{a}$ & $195 b$ & $324 \mathrm{c}$ \\
\hline 0 & $5.89 \mathrm{a}$ & $6.92 \mathrm{a}$ & $12.8 \mathrm{a}$ & $136 \mathrm{a}$ & $207 b$ & $343 b c$ \\
\hline 600 & $5.83 \mathrm{a}$ & $6.98 \mathrm{a}$ & $12.8 \mathrm{a}$ & $154 \mathrm{a}$ & $220 \mathrm{ab}$ & $374 a b c$ \\
\hline 1200 & $5.87 \mathrm{a}$ & $7.22 \mathrm{a}$ & $13.1 \mathrm{a}$ & $171 \mathrm{a}$ & $235 \mathrm{ab}$ & $406 \mathrm{ab}$ \\
\hline 1800 & $5.90 \mathrm{a}$ & $7.01 \mathrm{a}$ & $12.9 \mathrm{a}$ & $165 \mathrm{a}$ & $255 \mathrm{a}$ & $420 \mathrm{a}$ \\
\hline$p^{\ddagger}$ & $\mathrm{ns}^{\mathrm{b}}$ & $<0.001$ & $<0.01$ & $\mathrm{~ns}$ & $<0.05$ & $<0.05$ \\
\hline
\end{tabular}

${ }^{a}$ Controls received no basal dressing of poultry manure and no mineral fertilizer $\mathrm{N}$ but received $\mathrm{N}$ from irrigation water.

b No significance.

$\dagger$ Within each column, means followed by the same letter are not significantly different by Duncan's multiple range test at the $5 \%$ level.

* Significance of differences due to treatments by analysis of variance. 

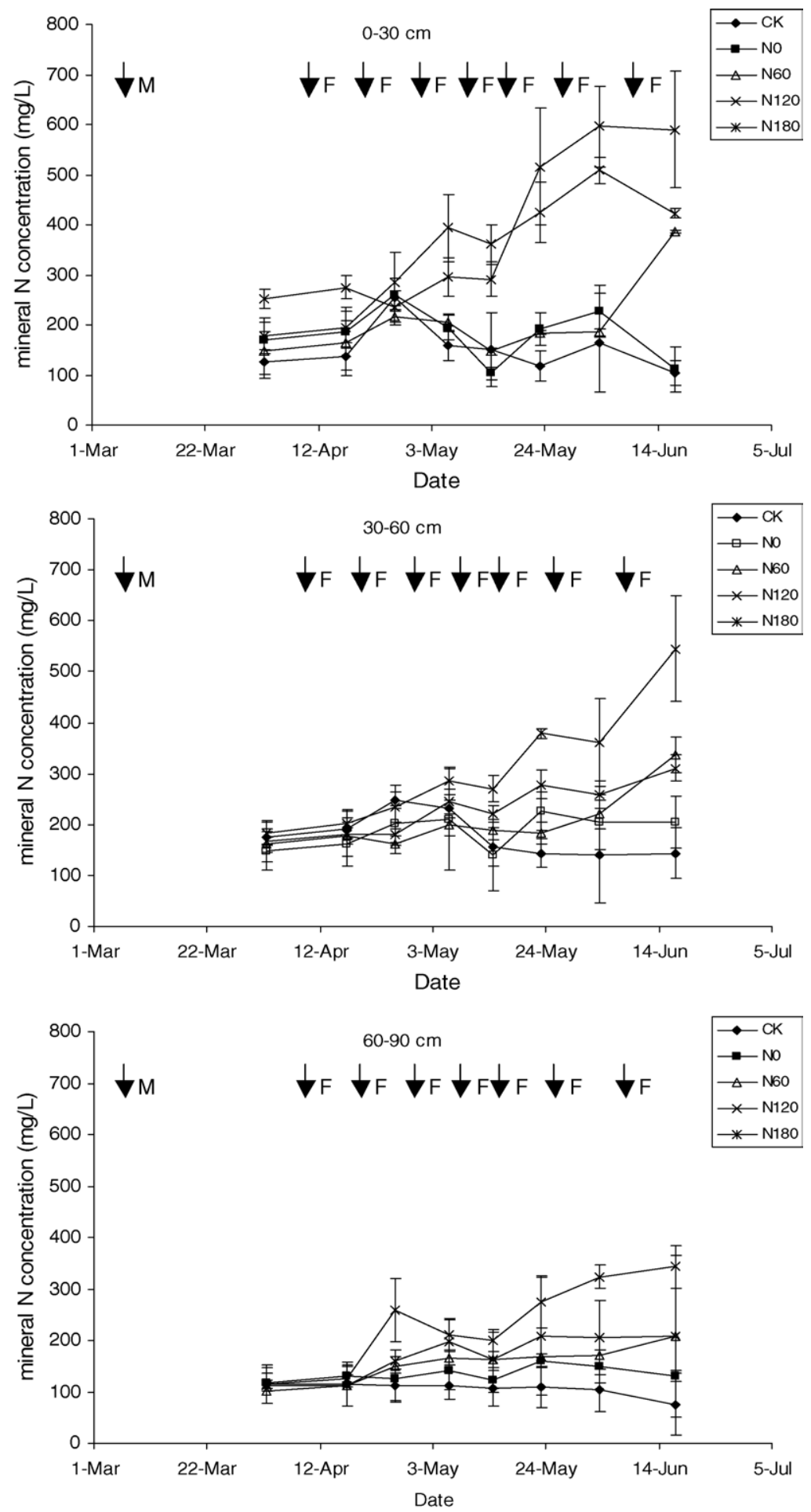

Fig. 3. Dynamics of available $\mathrm{N}$ in soil solution in different soil profiles. Arrows indicate dates of fertilizer application: $\mathrm{M}$, organic manure; F, fertilizer N; CK, control. 


\subsection{Dynamics of available $N$ during the cropping period}

Since the $\mathrm{NH}_{4}{ }^{+}-\mathrm{N}$ in the top $90 \mathrm{~cm}$ of the soil profile usually comprised less than $2 \%$ of total mineral $\mathrm{N}$ at each sampling date, soil $\mathrm{NO}_{3}{ }^{-}-\mathrm{N}$ concentration was considered representative of the level of available $\mathrm{N}$ during the cropping period. Four weeks after manure application, the mineral $\mathrm{N}$ concentration in the soil solution in the top $30 \mathrm{~cm}$ of the soil profile was $18-40 \%$ higher in plots receiving manure or fertilizer $\mathrm{N}$ than in the controls (Fig. 3). The increase in mineral $\mathrm{N}$ in the surface soil during this period was mainly available $\mathrm{N}$ from the manure and mineralization of soil organic N. After two top dressings, each comprising $10 \%$ of the total application rate of fertilizer $\mathrm{N}$, the mineral $\mathrm{N}$ concentration in the soil solution at 0 $30 \mathrm{~cm}$ depth increased in the three fertilizer $\mathrm{N}$ treatments, especially during May and June, when three further top dressings (each 20\% of the total application) were applied. The highest mineral $\mathrm{N}$ concentration in the soil solution at the top $30 \mathrm{~cm}$ (590 $\mathrm{m} \mathrm{L}^{-1}$ ) was found in the plots receiving the highest fertilizer $\mathrm{N}$ rate after the 7th top dressing in June, with decreasing concentrations as $\mathrm{N}$ inputs decreased. High $\mathrm{N}$ accumulation in the surface soil layer led to nitrate leaching down to the deeper soil layers (Fig. 4). Increasing $\mathrm{N}$ rate increased mineral $\mathrm{N}$

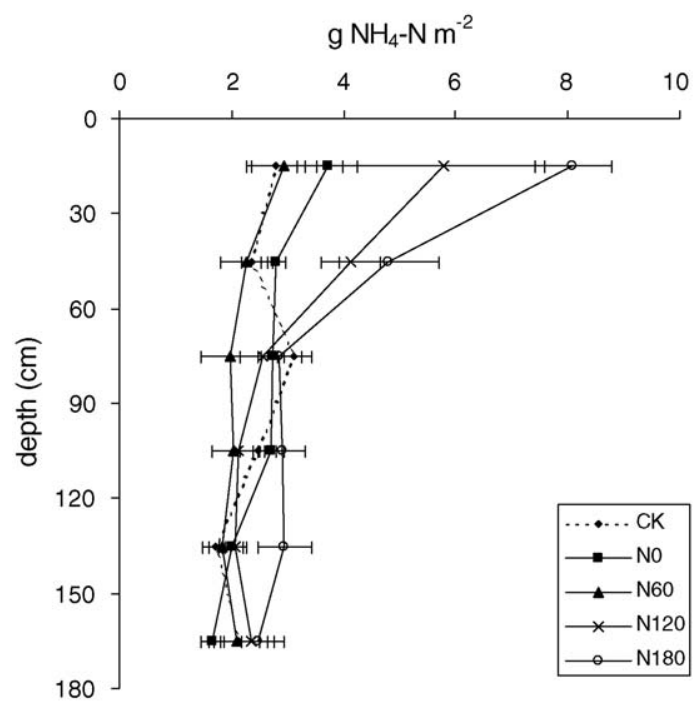

accumulation at $0-30 \mathrm{~cm}$ and also increased $\mathrm{N}$ leaching potential, although crop yield was not significantly affected by the rate of additional $\mathrm{N}$. The highest potential nitrate leaching loss was observed in plots receiving $1800 \mathrm{~kg}$ fertilizer $\mathrm{N} \mathrm{ha}^{-1}$, with mineral $\mathrm{N}$ concentrations at soil depths of 30-60 and 60-90 cm of about 304 and $212 \mathrm{mg} \mathrm{L}^{-1}$, respectively, higher than in unamended control plots. The organic manure with no mineral $\mathrm{N}$ fertilizer application also led to nitrate leaching, with mineral $\mathrm{N}$ concentrations at soil depths of $30-60$ and $60-90 \mathrm{~cm}$ of the order of 61 and $55 \mathrm{mg} \mathrm{L}^{-1}$ greater than in unamended controls, but these differences were not significant.

The quantities of $\mathrm{NO}_{3}{ }^{-}-\mathrm{N}$ at different soil depths down to $180 \mathrm{~cm}$ after harvest tended to confirm that nitrate leaching had occurred (Fig. 4). Although additional $\mathrm{N}$ inputs increased $\mathrm{NH}_{4}{ }^{+}-\mathrm{N}$ in the surface soil, $\mathrm{NO}_{3}{ }^{-}-\mathrm{N}$ was the dominant form of soil mineral $\mathrm{N}$ and leaching of $\mathrm{NH}_{4}{ }^{+}-\mathrm{N}$ would have been unlikely to occur. Application of organic manure did not significantly increase $\mathrm{NO}_{3}{ }^{-} \mathrm{N}$ the soil profile to $180 \mathrm{~cm}$ depth in the plots receiving manure but no fertilizer $\mathrm{N}$ compared to unamended controls. Increasing fertilizer $\mathrm{N}$ resulted in significant increases in $\mathrm{NO}_{3}{ }^{-}-\mathrm{N}$ in the top $90 \mathrm{~cm}$ of the soil profile and also between depths of 90 and $180 \mathrm{~cm}$. Most of the additional $\mathrm{N}$ had accumulated in the top $90 \mathrm{~cm}$ of the soil profile. Nitrate-N that had leached below this part

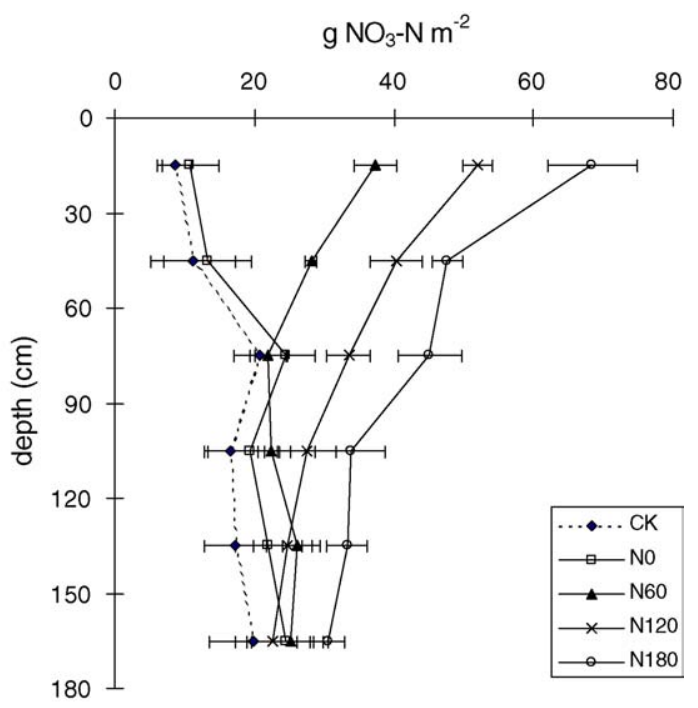

Fig. 4. Mineral N in different soil profiles after harvesting (July 2001). CK, control. 
of the profile would be too deep for uptake by the plant roots and would therefore be unavailable to the hot pepper crop.

\subsection{Nitrate leaching}

The total amount of water collected by the leachate collectors during the cropping period was 37$40 \mathrm{~L} \mathrm{~m}^{-2}$, representing about $10 \%$ of the irrigation water input and there were no significant differences among the treatments (Fig. 5). The amount of $\mathrm{NO}_{3}{ }^{-}-\mathrm{N}$ in leaching water at each sampling date is also shown in Fig. 5. The total amount of $\mathrm{NO}_{3}{ }^{-}-\mathrm{N}$ leached beyond the top $90 \mathrm{~cm}$ of the soil profile, calculated from the volume of leaching water and the $\mathrm{NO}_{3}{ }^{-}-\mathrm{N}$ concentration, was $16.6 \mathrm{~g} \mathrm{NO}_{3}{ }^{-}-\mathrm{N} \mathrm{m}^{-2}$ in unamended controls from a total input of $24.4 \mathrm{~g} \mathrm{NO}_{3}{ }^{-}-\mathrm{N} \mathrm{m}^{-2}$ from irrigation water during the whole season. The values for zero-fertilizer $\mathrm{N}$ plots and those receiving $60 \mathrm{~kg}$ fertilizer $\mathrm{N} \mathrm{ha}^{-1}(20.1$ and $22.4 \mathrm{~g} \mathrm{NO}_{3}^{-}-\mathrm{N} \mathrm{m}^{-2}$ ) were not significantly different from the controls. However, the two highest fertilizer $\mathrm{N}$ rates gave significantly higher values (34.5 and $54.2 \mathrm{~g} \mathrm{NO}_{3}{ }^{-}-\mathrm{N} \mathrm{m}^{-2}$ ). Leaching of $\mathrm{NH}_{4}{ }^{+}-\mathrm{N}$ was negligible because total amount of $\mathrm{NH}_{4}{ }^{+}-\mathrm{N}$ in the leaching water was often less than $1.0 \mathrm{~g} \mathrm{~m}^{-2}$ in all treatments.
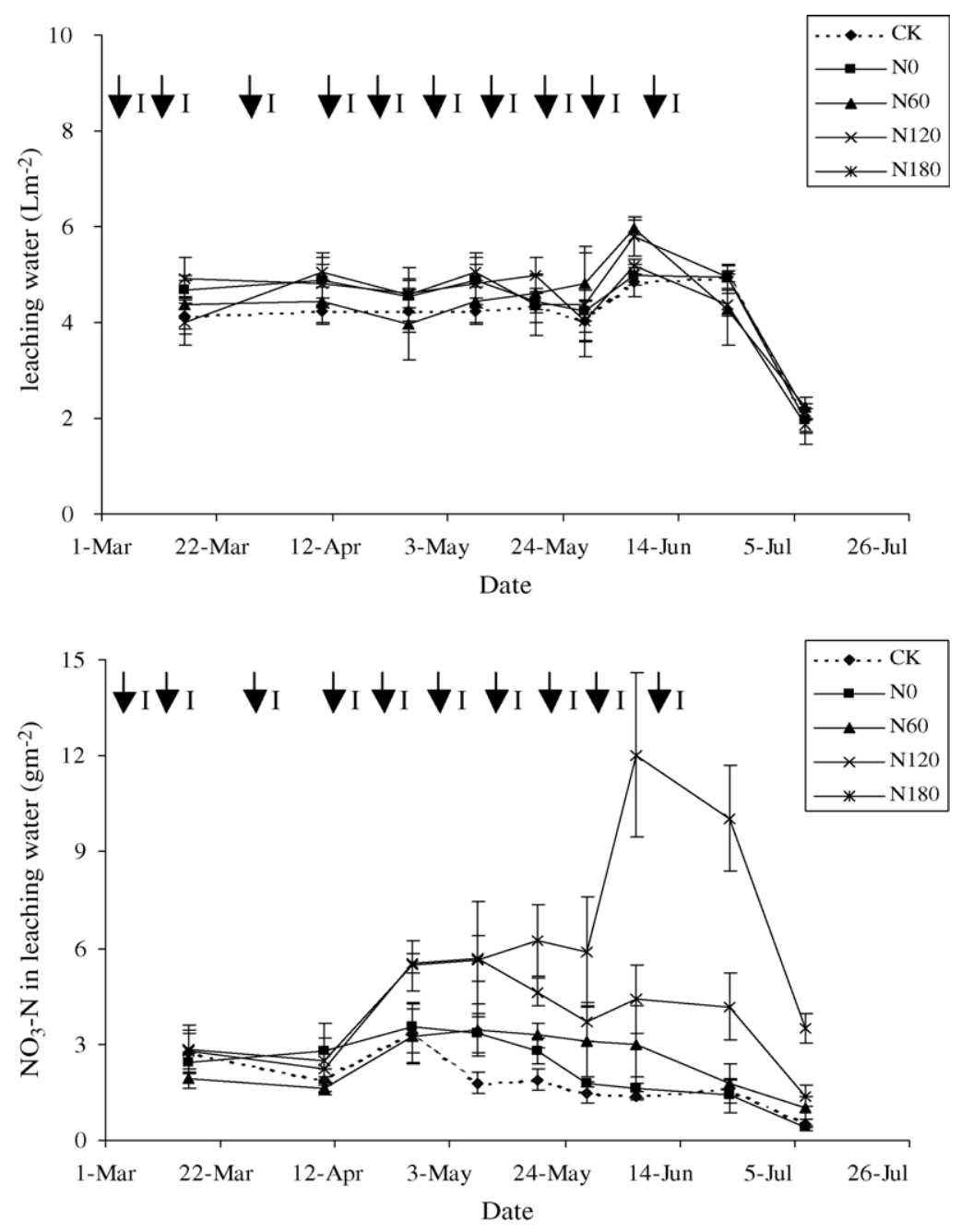

Fig. 5. Leachate volume and $\mathrm{NO}_{3}{ }^{-}-\mathrm{N}$ in leaching water collected on different sampling dates. Values are expressed on an area basis (per square metre of soil surface). CK, control. 
Table 4

$\mathrm{N}$ balance sheet for hot pepper plots receiving various $\mathrm{N}$ fertilizer application rates

\begin{tabular}{|c|c|c|c|c|}
\hline \multirow[t]{2}{*}{ Inputs and outputs $\left(\mathrm{kg} \mathrm{ha}^{-1}\right)$} & \multicolumn{4}{|c|}{ Ferilizer $\mathrm{N}$ application rate $\left(\mathrm{kg} \mathrm{ha}^{-1}\right)$} \\
\hline & 0 & 600 & 1200 & 1800 \\
\hline$N_{\min }$ before planting ${ }^{\text {a }}(0-90 \mathrm{~cm}$ soil depth $)$ & 1117 & 1117 & 1117 & 1117 \\
\hline Fertilizer N & 0 & 600 & 1200 & 1800 \\
\hline $\mathrm{N}$ in organic manure & 178 & 178 & 178 & 178 \\
\hline $\mathrm{N}$ in irrigation water & 254 & 254 & 254 & 254 \\
\hline Net $\mathrm{N}$ mineralization (or immobilization) ${ }^{\dagger}$ & -195 & -195 & -195 & -195 \\
\hline Total $\mathrm{N}$ input & 1354 & 1954 & 2554 & 3154 \\
\hline $\mathrm{N}$ offtake at harvest & 344 & 375 & 406 & 420 \\
\hline$N_{\min }$ after harvest $(0-90 \mathrm{~cm}$ soil depth) & 579 & 947 & 1383 & 1768 \\
\hline Total $\mathrm{N}$ recovery & 923 & 1322 & 1789 & 2188 \\
\hline $\mathrm{N}$ in leaching water & 210 & 231 & 353 & 554 \\
\hline $\mathrm{NH}_{3}-\mathrm{N}$ volatilized & 7 & 9 & 11 & 15 \\
\hline Total N losses & 217 & 240 & 364 & 569 \\
\hline Unaccounted for $\mathrm{N}$ & 214 & 392 & 401 & 397 \\
\hline
\end{tabular}

${ }^{\text {a }} N_{\min }$ values are for the $0-90 \mathrm{~cm}$ layer of the soil profile.

${ }^{\dagger}$ Net $\mathrm{N}$ mineralization $=\mathrm{N}$ recovery in $N_{0}-$ soil $N_{\min }$ before planting in $N_{0}$.

\subsection{Nitrogen balance}

The fertilizer $\mathrm{N}$ inputs used on crops in this region and in this experiment can be considered excessive, but they seem even more extreme when the total $\mathrm{N}$ inputs of the system are calculated (Table 4). The greenhouse used for the experiment was 4 years old, and therefore, had been used to grow seven or eight commercial vegetable crops before the experiment was established. Each of these crops would have received high fertilizer $\mathrm{N}$ inputs and poultry manure incorporated into the soil at rates similar to those used in our experiment. The result is an extremely high soil mineral $\mathrm{N}$ level $\left(1117 \mathrm{~kg} \mathrm{~N} \mathrm{ha}^{-1}\right)$ before planting and substantial inputs of $\mathrm{N}$ in the organic manure and irrigation water, giving a very large input of $1350 \mathrm{~kg} \mathrm{~N} \mathrm{ha}{ }^{-1}$ in addition to the fertilizer application. The amounts of calculated total $\mathrm{N}$ lost from the system by leaching and $\mathrm{NH}_{3}$ volatilization were very large, especially, when combined with the $\mathrm{N}$ unaccounted for in the $\mathrm{N}$ balance sheet (Table 4) and increased with increasing fertilizer $\mathrm{N}$ application rate. At the average commercial fertilizer application rate of $1200 \mathrm{~kg} \mathrm{~N} \mathrm{ha}^{-1}$, the total $\mathrm{N}$ loss and the $\mathrm{N}$ unaccounted for each comprised about the same amount as that removed by the crop and from Table 3, it is clear that crop $\mathrm{N}$ offtake was higher than required for optimum fruit yield.

\subsection{Recovery of ${ }^{15} \mathrm{~N}$-labelled fertilizer $N$}

Table 5 shows the proportion of applied fertilizer $\mathrm{N}$ that was recovered in the soil profile, in the crop

Table 5

Percent recovery of ${ }^{15} \mathrm{~N}$-labelled fertilizer $\mathrm{N}$ applied at $1200 \mathrm{~kg} \mathrm{~N} \mathrm{ha}^{-1}$ to microplots of hot pepper in soil and crop aboveground parts at harvest

\begin{tabular}{lcc}
\hline Component & $\begin{array}{l}\text { Residual }{ }^{15} \mathrm{~N} \\
\left(\mathrm{~kg} \mathrm{~N} \mathrm{ha}^{-1}\right)^{\mathrm{a}}\end{array}$ & $\begin{array}{l}\text { Recovery of } \\
\text { applied }{ }^{15} \mathrm{~N}(\%)\end{array}$ \\
\hline $0-30 \mathrm{~cm}$ soil depth & $41.9 \pm 12.3$ & 34.9 \\
$30-60 \mathrm{~cm}$ soil depth & $2.8 \pm 1.1$ & 2.3 \\
$60-90 \mathrm{~cm}$ soil depth & $0.5 \pm 0.3$ & 0.4 \\
$90-120 \mathrm{~cm}$ soil depth & $2.4 \pm 1.3$ & 2.0 \\
$120-150 \mathrm{~cm}$ soil depth & $2.8 \pm 1.9$ & 2.3 \\
$150-180 \mathrm{~cm}$ soil depth & $3.5 \pm 0.7$ & 2.9 \\
$0-90 \mathrm{~cm}$ soil depth & $45.2 \pm 12.0^{\mathrm{a}}$ & 37.7 \\
Offtake in crop & $12.6 \pm 3.6$ & 10.5 \\
Unaccounted for loss ${ }^{\dagger}$ & 62.2 & 51.8 \\
\hline a Results are means \pm one standard deviation. \\
${ }^{\dagger}{ }^{15} \mathrm{~N}$ not recovered in crop or top 90 cm of soil profile, unac- \\
counted for loss includes $8.7 \mathrm{~kg}$ ha $^{-1}$ recovered in 90-180 cm of soil \\
profile.
\end{tabular}


aboveground parts and calculated to be lost from the system (i.e. the aerial parts of the crop and the top $90 \mathrm{~cm}$ of the soil profile) at harvest. Only about $10 \%$ of the fertilizer $\mathrm{N}$ was recovered in the crop and about $35 \%$ was found in the top $30 \mathrm{~cm}$ of the soil profile, with about $38 \%$ in the top $90 \mathrm{~cm}$ of the soil profile. Small and increasing amounts $(2-3 \%)$ were also measured in deeper $30 \mathrm{~cm}$ layers of the soil to $180 \mathrm{~cm}$ depth, indicating some movement of fertilizer $\mathrm{N}$ into the subsoil. Soil mineral $\mathrm{N}$ is often determined to a standard soil depth of $90 \mathrm{~cm}$. If about $52 \%$ of fertilizer $\mathrm{N}$ were lost from the system (Table 5), this would correspond to a loss of over $620 \mathrm{~kg} \mathrm{~N} \mathrm{ha}^{-1}$. If two similar crops were grown each year, the loss of fertilizer $\mathrm{N}$ on an annual basis would amount to approximately $1240 \mathrm{~kg} \mathrm{~N} \mathrm{ha}^{-1}$. Even allowing for some gaseous losses of $\mathrm{N}$ to account for part of this loss, this represents a very serious threat to groundwater quality.

\subsection{Ammonia volatilization}

Losses of $\mathrm{N}$ due to $\mathrm{NH}_{3}$ volatilization from the soil surface were usually calculated to be less than $1.5 \mathrm{~g} \mathrm{~N} \mathrm{~m}^{-2}$ during the whole growing season under all treatments (data not presented). Other possible routes of $\mathrm{N}$ loss may have included $\mathrm{N}$ assimilation by soil microorganisms, denitrification and plant $\mathrm{NH}_{3}$ volatilization, but these were not measured directly in our experiment.

\subsection{Well water survey}

Well water $\mathrm{NO}_{3}{ }^{-}-\mathrm{N}$ concentrations averaged $14 \mathrm{mg} \mathrm{L}^{-1}$ (range 3-71 $\mathrm{mg} \mathrm{L}^{-1}$ ), corresponding very closely with the results of Zhang et al. (1996). The four areas of Shouguang differed significantly $(p<0.05$ by analysis of variance) in mean groundwater $\mathrm{NO}_{3}{ }^{-}-$ $\mathrm{N}$ concentration, with wells in the northern and eastern sectors where most of the commercial greenhouses are located showing the highest values. Almost half of the wells $(46 \%)$ contained water exceeding the USEPA public drinking water maximum contaminant level of $10 \mathrm{mg} \mathrm{N} \mathrm{L}^{-1}$ after 20 years of expansion of vegetable cropping, a result remarkably similar to that $(42 \%)$ found in a small arid mountainous rural area of California in which nitrate from anthropogenic sources (septic tank leachate and animal manures) had accumulated in the groundwater over a period of 50 years (Williams et al., 1998). There is anecdotal evidence of the water table lowering with time at Shouguang, and we found high conductivity levels in the soil samples from our experiment, indicating a potential soil salinization problem (data not shown).

\section{Conclusions}

A crop recovery of fertilizer $\mathrm{N}$ of $40 \%$ would be regarded as inefficient enough to cause concern in most parts of the world. A crop recovery of only $11 \%$ is thus both extremely low and extremely inefficient. The situation is made even more serious by the extremely high application rates of $\mathrm{N}$ in the soil-plant system. By comparison, the recommended $\mathrm{N}$ inputs for hot pepper cultivation in Taiwan presented by Berke et al. (1999) (from all sources: soil, fertilizer, crop residues and compost) was $450 \mathrm{~kg} \mathrm{ha}^{-1}$ for an expected fruit yield of $5 \mathrm{t} \mathrm{DM} \mathrm{ha}^{-1}$. Even if we adjust this up to $\sim 500 \mathrm{~kg} \mathrm{~N} \mathrm{ha}^{-1}$ for an expected yield of about $6 \mathrm{tha}^{-1}$ in Shouguang (Table 3), the plots with no fertilizer $\mathrm{N}$ application in our experiment were receiving almost three times this input from the poultry manure, soil mineral $\mathrm{N}$ and $\mathrm{N}$ in the irrigation water (Table 4). Clearly, the fertilizer $\mathrm{N}$ inputs used in this part of north China are intended to produce maximum yield, but the inputs are so extreme that soil and groundwater quality (and eventually crop quality and possibly the health of consumers) may be likely to deteriorate and the system is clearly unsustainable. Further research is urgently required to determine the appropriate $\mathrm{N}$ inputs for optimum yield of each type of vegetable grown in both open field and greenhouse cultivation systems for safe and sustainable production. Steps must be taken soon to lower fertilizer N inputs in this region to avoid serious environmental degradation and the potential threat to human health from excessive $\mathrm{NO}_{3}{ }^{-}-\mathrm{N}$ in both drinking water and the diet (NCAHS, 1989; Weyer, 2001) over a very wide area.

\section{Acknowledgements}

We thank the National Natural Science Foundation of China (Project 30230250), the '863' Project 
(2001AA247031) and the Royal Society of London (Project 15360) for generous financial support.

\section{References}

Barraclough, D., Jarvis, S.C., Davies, G.P., Williams, J., 1992. The relations between fertilizer nitrogen application and nitrate leaching from grazed grassland. Soil Use Manage. 8, 51-56.

Berke, T.G., Black, L.L., Green, S.K., Morris, R.A., Talekar, N.S., Wang, J.F., 1999. Suggested cultural practices for chili pepper. Publication No. 00-483. Asian Vegetable Research and Development Center, Taiwan.

Biernbaum, J.A., 1992. Root-zone management of greenhouse container-grown crops to control water and fertilizers use. Hort. Technol. 2, 127-132.

Cameron, K.C., Di, H.J., McLaren, R.G., 1997. Is soil an appropriate dumping ground for our wastes? Aust. J. Soil Res. 35, 9951035.

Jabro, J.D., Stout, W.L., Fales, S.L., Fox, R.H., 1997. Nitrate leaching from soil core lysimeters treated with urine or feces under orchardgrass: measurement and simulation. J. Environ. Qual. 26, 89-94.

Jackson, L.E., Stivers, L.J., Warden, B.T., Tanji, K.K., 1994. Crop nitrogen utilization and soil nitrate loss in a lettuce field. Fert. Res. 37, 93-105.

Kengni, L., Vachaud, G., Thony, J.L., Laty, R., Garino, B., Casabianca, H., Jame, P., Viscogliosi, R., 1994. Field measurements of water and nitrogen losses under irrigated maize. J. Hydrol. $162,23-46$.

Li, J.L., Zhu, J.H., Zhang, X.S., Meng, X.X., Chen, Q., Li, X.L., Zhang, F.S., 2001. Nitrate leaching loss from soil and nutrient utilization by tomato in protected field. Chin. J. Appl. Environ. Biol. 7, 126-129.
MacDonald, A.J., Powlson, D.S., Poulton, P.R., Jenkinson, D.S., 1989. Unused fertilizer nitrogen in arable soils: its contribution to nitrate leaching. J. Sci. Food Agric. 46, 407-419.

McNeal, B.L., Stanley, C.D., Graham, W.D., Gilreath, P.R., Downey, D., Creighton, J.F., 1995. Nutrient loss trends for vegetable and citrus fields in west central Florida: I. Nitrate. J. Environ. Qual. $24,95-100$.

McPharlin, I.R., Aylmore, P.M., Jeffery, R.C., 1995. Nitrogen requirements of lettuce under sprinkler irrigation and trickle fertigation on a Spearwood sand. J. Plant Nutr. 18, 219-241.

Moyer, J.W., Saporito, L.S., Janke, R.R., 1996. Design, construction and installation of an intact soil core lysimeter. Agron. J. 88, 253-256.

National Coalition for Agricultural Health and Safety (NCAHS), 1989. Agriculture at risk: a report to the nation. Institute of Agricultural Medicine and Occupational Health, The University of Iowa, Iowa City, IA.

Power, J.F., Schepers, J.S., 1989. Nitrate contamination of groundwater in North America. Agric. Ecosyst. Environ. 26, 165-187.

Rossi, N., Ciavatta, C., Vittori Antisari, L., 1991. Seasonal pattern of nitrate losses from cultivated soil with subsurface drainage. Water Air Soil Pollut. 60, 1-10.

Weyer, P., 2001. Nitrate in drinking water and human health. Review Paper for the University of Illinois Urbana-Champaign Agriculture Safety and Health Conference. www.cheec.uiowa.edu/ nitrate/health.html

Williams, A.E., Johnson, J.A., Lund, L.J., Kabala, Z.J., 1998. Spatial and temporal variations in nitrate contamination of a rural aquifer. Calif. J. Environ. Qual. 27, 1147-1157.

Zhang, W.L., Tian, Z.X., Zhang, N., Li, X.Q., 1996. Nitrate pollution of groundwater in northern China. Agric. Ecosyst. Environ. 59, 223.

Zhu, J.H., Li, X.L., Zhang, F.S., Li, J.L., Christie, P., 2004. Responses of greenhouse tomato and pepper yields and nitrogen dynamics to applied compound fertilizers. Pedosphere 14, $213-$ 222. 